\title{
METHODS FOR MEASURING THE ACTIVITY OF COMPONENTS OF THE STREPTOCOCCAL FIBRINOLYTIC SYSTEM, AND STREPTOCOCCAL DESOXYRIBONUCLEASE ${ }^{1}$
}

\author{
BY L. R. CHRISTENSEN \\ (From the Department of Microbiology, New York University College of Medicine, \\ New York City)
}

(Received for publication September 22, 1948)

Studies of the effects of streptokinase and desoxyribonuclease from hemolytic streptococci on certain pathological processes, reported' in an accompanying paper (1), necessitated the development of quantitative methods suitable for routine laboratory assay of the various substances known to affect the streptokinase-plasminogen (streptococcal fibrin-lysing) system. Methods were devised, or earlier methods modified, for the routine assay of streptokinase (streptococcal fibrinolysin), antistreptokinase (antifibrinolysin), serum inhibitor (serum trypsin inhibitor), and plasminogen (serum protease, serum fibrinolysin, serum tryptase).

\section{MATERIALS}

1. Crude streptokinase: ${ }^{2}$ The method used for production of streptokinase is based on one previously published (2), but differs principally in the use of ethanol as a precipitant rather than ammonium sulfate.

Cultures of Group C strain H46A are grown in the presence of high glucose concentration, employing intermittent neutralization with $\mathrm{NaOH}$ in the manner previously reported (2). The yields of streptokinase and desoxyribonuclease from a typical culture are presented in Figure 1. It will be noted that the peaks of enzyme production coincide with the peak of glucose utilization. As incubation is continued, both streptokinase and desoxyribonuclease levels decline. For this reason it is best to begin harvesting of the culture shortly before glucose utilization ceases.

1 This study was supported in part by a grant from the Life Insurance Medical Research Fund and the Ralph B. Rogers Rheumatic Fever Fund.

2 We are greatly indebted to Dr. Benjamin Carey and Mr. J. N. Adam, Jr. of the Lederle Laboratories Division of the American Cyanamid Company for supplying large quantities of crude streptokinase for these studies.
At the end of the growth period the cells are removed by Sharples centrifugation at about $40,000 \mathrm{rpm}$. The supernatant is adjusted to $\mathrm{pH}$ $3.8-4.2$ by the addition of glacial acetic or hydrochloric acid. Cold ethanol at $-8^{\circ} \mathrm{C}$ is added to the supernatant at room temperature to a final concentration of $40-50 \%$. After standing overnight in the cold, the practically clear supernatant is siphoned off and the flocculent precipitate, which contains the streptokinase and desoxyribonuclease, is collected by centrifugation at 2,000-3,000 $\mathrm{rpm}$. The precipitate is dissolved in borate buffer with the aid of alkali, adjusted to $\mathrm{pH} 7.8-8.0$, and lyophilized. This precipitate contains the cells not sedimented by Sharples centrifugation, vari-

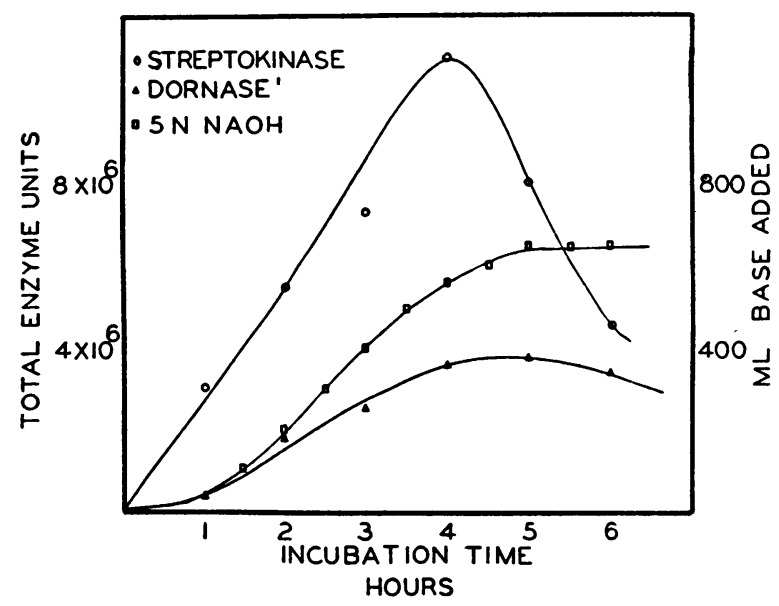

Fig. 1. Relation of Streptokinase and Desoxyribonuclease Production to Growth (Expressed as Ml. 5N NaOH Added to Neutralize Acid Formed)

1 Desoxyribonuclease.

ous streptococcal proteins, some media components, nucleic acids, streptokinase and desoxyribonuclease.

2. Purified streptokinase: The purification procedure is a modification of an earlier method (3). A $2-5 \%$ solution of crude streptokinase is made 
in borate buffer, $\mathrm{pH}$ 7.8-8.0. Cells and insoluble debris are spun out at $16,000 \mathrm{rpm}$ in a refrigerated angle centrifuge. Occasionally a significant portion of the activity is also spun down by this treatment. If this is the case, the precipitate is resuspended and made alkaline to thymol blue (above $\mathrm{pH} 9$ ). The solution is then adjusted to $\mathrm{pH} \quad 7.8-8.0$ and centrifuged. Following this treatment the activity remains in solution. The supernatants are pooled and diluted with distilled water to a nitrogen content of about 0.25-0.50 $\mathrm{mg}$. $/ \mathrm{ml}$. and sufficient Pillimer's acetate buffer is added (4) to reduce the $\mathrm{pH}$ to 5.6. Sufficient $1 \%$ protamine $^{3}$ solution in distilled water is added to cause the formation of a flocculent precipitate (usually about $1 \mathrm{ml} . / 5-10 \mathrm{mg}$. nitrogen). The protamine precipitate is spun out in a refrigerated angle centrifuge at 4,000-5,000 rpm. The supernatant should show no further precipitation on testing with protamine, but care should be used to avoid any great excess of protamine, since it will complicate later purification steps. The supernatant is cooled to about $0^{\circ}$ and ethanol at $-10^{\circ}$ to $-20^{\circ}$ is added to a final concentration of $20 \%$. On standing overnight at $-8^{\circ}$ to $-10^{\circ}$ a flocculent precipitate forms which is spun off in an angle centrifuge in the cold. The precipitate is dissolved in borate buffer, $\mathrm{pH}$ 7.88.0. Some insoluble material remains in suspension, but in most cases little activity is associated with it; and it can be removed by centrifugation, resulting in little or no decrease in total activity, but a decrease of about $50 \%$ in total nitrogen. The clear solution usually contains between 100 and 180 units of streptokinase per microgram of nitrogen. Recovery usually represents about $25 \%$ of the original activity of the culture, some $50 \%$ of the original activity being lost during the initial Sharples centrifugation. Desoxyribonuclease, which has accompanied streptokinase in the previous purification steps, is separated from streptokinase by the $20 \%$ ethanol fractionation.

\footnotetext{
8 Several sources of protamine have been tested. In our experience, consistently good results are obtained with Squibb protamine. Protamines from other sources often fail to effect purification, and are less efficient in that much larger quantities are necessary to precipitate inert materials. We wish to express our gratitude to E. R. Squibb and Sons for generous gifts of protamine.
}

Practically all of the desoxyribonuclease activity remains in the supernatant.

The purified streptokinase is sterilized by filtration through Seitz or Selas filters, lyophilized and stored in the refrigerator. Solutions remain stable for several weeks if not too dilute and if kept in the cold.

3. Streptococcal desoxyribonuclease: As mentioned in previous reports (5-7), streptococcal cultures contain a potent desoxyribonuclease. In the original method of purification (2) using ammonium sulfate, both enzymes were found in the same fraction. However, they are readily separated since streptokinase is precipitated at $\mathrm{pH}$ 5.6 by $20 \%$ ethanol or $50 \%$ ammonium sulfate, while the majority of the desoxyribonuclease remains in solution. In the present study, desoxyribonuclease was prepared by bringing the $20 \%$ ethanol supernatant of the above protamine-purified streptokinase precipitate to $40-50 \%$ ethanol. The precipitate which forms overnight in the cold is collected by centrifugation and dissolved in the gelatin-magnesium-veronal buffer recommended for desoxyribonuclease titration by McCarty (8). The preparations usually contain insoluble material, with which is associated some of the desoxyribonuclease activity. The clear supernatant obtained by centrifugation of the material, however, contains a significant proportion of activity.

Up to the present time methods have not been perfected for the quantitative isolation of the enzyme from streptococcal cultures and recovery represents only a fraction of the amount in the

TABLE I

Fractionation of streptokinase and desoxyribonuclease from streptococcal cultures

\section{Fraction}

(1) original culture

(2) after Sharples centrifugation

(3) alcohol precipitate of culture super-

natant protamine supernatant

(5) $40 \%$ alcohol ppt. o (4) supernatant

* This value is somewhat lower than the true value because sufficient time for reversal of the inactivation, which occurs in the neighborhood of pH 5 (3), was not allowed before titration. 
original culture. This loss is due apparently to the instability of the enzyme.

In Table I are presented the data obtained in a typical purification experiment.

4. Bovine fibrinogen: For reasons to be discussed later, human fibrinogen preparations were considered unsuitable for assay purposes. Armour's Fraction I of bovine plasma, ${ }^{4}$ a commercial product, has been found to be quite suitable for our purposes, since it contains no antistreptokinase, serum inhibitor or plasminogen activatable by streptokinase. The dry powder is stored in the refrigerator and dissolved in borate buffer, $\mathrm{pH}$ 7.4-7.6, in appropriate concentrations before use. Solutions are reasonably stable and generally remain usable for six to eight hours if kept cool.

5. Plasminogen: No satisfactory preparation of plasminogen is available. The purer preparations with which we are familiar, such as Howard Fraction III-2,3 (9), contain plasmin as well as plasminogen and proteolytic products of fibrin. The cruder preparations, prepared by salt fractionation $(2)$, isoelectric precipitation $(2,10)$ or ethanol fractionation, such as Harvard Fraction III (11), contain a variety of substances, some of which undoubtedly influence the streptokinaseplasminogen reaction. However, reproduceable results have been obtained in these laboratories by using a single lot of Harvard Fraction III. ${ }^{5}$ For use, the material is made up in borate buffer in a concentration of $0.25 \%$. The solutions must be used immediately, and kept in an ice bath, because some spontaneous plasmin activity will develop in a few hours. However, when used as outlined, we have noted no variation in the plasminogen titer of the dry material in over a year.

6. Standard antistreptokinase: A pool of Harvard Fraction II-III was fractionated by Harvard method 9 (12). Fraction II, the antibody fraction, was lyophilized and stored in a vacuum dessicator. ${ }^{\circ}$ Assay of the material with strepto-

4 We are indebted to Dr. J. B. Lesh of Armour Laboratories for supplying the Fraction I used throughout this study. Fraction $I$ is an ethanol fraction of bovine plasma and consists largely of fibrinogen.

5 We are indebted to Dr. Dwight Mulford, Division of Biologic Laboratories, Massachusetts State Department of Health, for supplying a large lot of Fraction III isolated from a single pool of plasma.

6 The author wishes to express his indebtedness to Dr. J. W. Williams and associates of the Department of kinase indicated that $1 \mathrm{mg}$. would inhibit the activity of 10 units of streptokinase, when tested by the method outlined below. The material was assigned, therefore, a value of 10 antistreptokinase units per mg., and used throughout these studies as a primary standard to check the constancy of the streptokinase unit and of the antistreptokinase titrations.

7. Crystalline trypsin: A solution of commercial crystalline trypsin, obtained from the Plaut laboratories, is prepared in $\mathrm{N} / 400 \mathrm{HCl}$. The stock solution contains $0.1 \%$ of the dry powder, of which about $50 \%$ is magnesium sulfate. The concentration of active trypsin in the solution is determined by titration with soybean inhibitor, as outlined below, and appropriate dilutions for use, usually containing $20 \mu \mathrm{g}$. of active trypsin per milliliter, are made up in borate buffer immediately before use.

8. Crystalline soybean inhibitor: A stock solution of Kunitz' crystalline inhibitor ${ }^{2}$ (13), containing $2 \mathrm{mg} . / \mathrm{ml}$. of inhibitor, was prepared in borate buffer. Appropriate dilutions are made up in borate buffer, $\mathrm{pH}$ 7.4-7.6, before use.

9. The preparation of other reagents, such as borate buffer and gelatin buffer, have been detailed in previous reports $(2,14)$.

\section{METHODS}

1. Streptokinase assay: Many methods have been described for streptokinase assay, utilizing clots prepared from human fibrinogen (15-18). These methods depend on the presence of plasminogen as a contaminant of the fibrinogen preparations, since, as Milstone (10) has shown, highly purified human fibrinogen will not lyse in the presence of streptokinase unless another serum factor (lysin factor, plasminogen) is added. In our experience, methods utilizing human fibrinogen are unsuitable for long-term routine use. The principal disadvantage is the variation from batch to batch in the fibrinogen-plasminogen ratio obtained with different methods of prepa-

Physical Chemistry of the University of Wisconsin for making facilities available and for help in the preparation of various plasma fractions.

7 Dr. M. Kunitz kindly supplied us with a preparation of crystalline soybean inhibitor for use as a standard, and made available his assay methods in advance of publication. 
ration, and even with the same method. For example, in our experience ethanol fractions of plasma, such as Harvard I, contain less plasminogen than do the salt fractionations previously used in this laboratory (2), as shown by the fact that clots treated with streptokinase will lyse much more readily if the fibrinogen is prepared by salt fractionation rather than the ethanol. Also, human fibrinogen preparations are unstable, due to the spontaneous conversion of plasminogen to plasmin. Another difficulty in the use of human fibrinogen is the presence of variable amounts of antibody globulin in the preparations. While this occasions no particular difficulty with most samples of normal plasma whatever the method of fractionation, we have encountered occasional lots of plasma with such high titers of antistreptokinase that they were unusable.

For these reasons, we have modified the test by the substitution of clots prepared from bovine fibrinogen (Armour's Fraction I). The bovine fibrinogen contains no plasminogen or plasmin, as shown by the fact that such clots, without added protease, will remain stable for days in the presence or absence of streptokinase. Antistreptokinase and inhibitor titrations indicate the absence of these substances also. As a source of plasminogen we have used a single large lot of Harvard Fraction III. The fibrinogen concentration used is $0.1 \%$, as in previous reports, and the concentration of Fraction III is adjusted to give a streptokinase unit equal in value to the one previously employed in this laboratory (3). The streptokinase assay is performed as follows:

$0.1 \mathrm{ml}$. streptokinase dilution in gelatin buffer

$0.4 \mathrm{ml}$. bovine fibrinogen, $0.25 \%$ in borate buffer

$0.5 \mathrm{ml}$. Fraction III, $0.25 \%$ in borate buffer. (This solution must be prepared just before use, and should be kept on ice)

$0.1 \mathrm{ml}$. Lederle Hemostatic Globulin, ${ }^{8}$ diluted $1: 3$ in borate buffer.

8 Lederle Hemostatic Globulin has recently become unavailable. Parke-Davis bovine thrombin may be substituted as well as Upjohn thrombin. They are less stable than Hemostatic Globulin when in solution in borate buffer, and solutions must be titrated frequently to determine the minimum amount necessary to form a firm clot. These preparations are more stable in glycerol solution, but we have not used glycerol solutions.
The tubes are incubated at $35^{\circ}$ and the lysis time of each tube of the series noted. The dilution lysing the clot in 10 minutes contains one unit and is determined by interpolation as outlined in a previous report (3).

2. Antistreptokinase: The antistreptokinase unit is defined as the amount of antibody required to inhibit 1 unit of streptokinase to such a degree that it will not activate the plasminogen sufficiently to cause lysis of the standard test clot in 30 minutes. Other methods of antistreptokinase assay have been presented $(15,18-20)$ but no general agreement has been reached on a method. We have thought it preferable to base the antibody unit on the method of streptokinase titration used in this laboratory. In order to have a primary standard of reference throughout the study, a lot of Fraction II, the gamma globulin fraction of human serum, was prepared and lyophilized. This preparation contained 10 antistreptokinase units per mg., and has been used as a reference standard for streptokinase and antistreptokinase titrations. Standardization of streptokinase with standard antibody is performed as follows:

$0.5 \mathrm{ml}$. streptokinase dilutions in gelatin buffer, $\mathrm{pH} 7.6-7.8$

$0.5 \mathrm{ml}$. standard antibody solution, containing 2 antistreptokinase units per $\mathrm{ml}$. (The antibody solution is heated at $56^{\circ}$ for $30-45$ minutes to destroy the small amount of of plasminogen and inhibitor which it contains.)

The mixture of streptokinase and antibody is incubated at $35^{\circ}$ for 30 minutes. At the end of this time, the following reagents are added:

$0.5 \mathrm{ml}$. of a $0.25 \%$ solution of Fraction III $0.5 \mathrm{ml}$. of $0.5 \%$ bovine fibrinogen

$0.1 \mathrm{ml}$. Hemostatic Globulin, diluted 1:3.

The tubes are incubated for another 30 minutes and the highest dilution of streptokinase which fails to lyse the clot is taken as the end point. A solution of crude or purified streptokinase standardized in this manner should show no significant change in titer over a period of a week or two if the streptokinase concentration is above about 2,000 units per ml. for the crude and above 
10,000 units per ml. for the purified. More dilute solutions are not quite so stable, probably because of denaturation occurring in dilute protein solutions. However, in practice, the streptokinase solution is standardized every day or two.

In determining the antistreptokinase titer of serum the serum must be heated at $56^{\circ}$ for $30-45$ minutes to destroy the plasminogen and inhibitor which it contains. As may be seen in Table II,

TABLE II

Effect of heating serum at $56^{\circ} \mathrm{C}$ for 30 minutes on serum inhibitor and antistreptokinase

\begin{tabular}{c|c|c|c|c}
\hline \hline \multirow{2}{*}{$\begin{array}{c}\text { Serum } \\
\text { number }\end{array}$} & \multicolumn{2}{|c|}{$\begin{array}{c}\text { Inhibitor equivalent to } \\
\text { micrograms try psin }\end{array}$} & \multicolumn{2}{|c}{ Antistreptokinase } \\
\cline { 2 - 5 } & $\begin{array}{c}\text { before } \\
\text { heating }\end{array}$ & $\begin{array}{c}\text { after } \\
\text { heating }\end{array}$ & $\begin{array}{c}\text { cefore } \\
\text { heating }\end{array}$ & $\begin{array}{c}\text { after } \\
\text { heating }\end{array}$ \\
\hline 1 & 1000 & 100 & 128 & 128 \\
2 & 500 & 80 & 64 & 64 \\
3 & 1000 & $-80^{*}$ & 64 & 32 \\
4 & 667 & 100 & 64 & 32 \\
5 & 667 & $-80^{*}$ & 128 & 64 \\
6 & 667 & $-80^{*}$ & 16 & 8 \\
7 & 1800 & 120 & 2560 & 2560 \\
8 & 800 & 48 & 3200 & 3200 \\
\hline
\end{tabular}

* Inhibitor equivalent to less than $80 \mu \mathrm{g}$.

heating reduces the inhibitor concentration by approximately $90 \%$, and produces no significant change in the antibody titer. A more valid reason for heating the serum than for the inactivation of inhibitor is to destroy plasminogen, since if this is not done, in the case of sera with a low antibody content, the tubes containing the lowest dilutions of serum will lyse the standard clot because of the activation of the plasminogen in the serum by uncombined streptokinase.

The inactivated serum is titrated for antistreptokinase as follows:

\section{$0.5 \mathrm{ml}$. inactivated serum dilution}

$0.5 \mathrm{ml}$. streptokinase solution, diluted in gelatin buffer to contain about 1-2 units.

The tubes are incubated for 30 minutes, and the remainder of the titration carried out as above. The end point is taken as the highest dilution of serum preventing lysis of the clot, and contains antistreptokinase equivalent to the streptokinase in the test.

3. Serum inhibitor: A number of methods have been devised in the last few years for the quantitative estimation of serum inhibitor $(14,18,21-$
23). These methods, however, have certain disadvantages for routine use.

Kunitz (13) has shown that crystalline soybean inhibitor undergoes an immediate, stoichiometric, irreversible reaction with trypsin, and that active trypsin can readily be determined by titration of the amount of soybean inhibitor necessary to inhibit the proteolytic activity of the trypsin sample, since the two are equivalent, weight for weight. Schmitz (24) has isolated a small amount of inhibitor from serum which he concluded was probably identical with the pancreatic inhibitor. It has also been shown (14) that serum and pancreatic inhibitor behave in the same way toward trypsin and toward plasmin, although the two inhibitors behave toward trypsin in a quantitatively and perhaps qualitatively different manner than they behave toward plasmin. In view of these facts it was decided to determine the inhibitory power of serum in terms of its ability to inhibit trypsin rather than plasmin. Additional reasons influencing this decision were as follows: (a) crystalline trypsin is readily available and easily standardized, whereas no plasmin preparations of comparable purity are known; $(b)$ trypsin is much more susceptible to the action of inhibitor than is plasmin; and (c) active trypsin can be conveniently stored in a stable solution (in $\mathrm{M} / 400 \mathrm{HCl}$ ) while plasminogen and plasmin preparations are very unstable $(14,25,26)$.

Standardization of trypsin with soybean inhibitor is carried out as follows:

$0.5 \mathrm{ml}$. freshly prepared dilutions of stock trypsin in borate buffer, $\mathrm{pH}$ 7.4-7.6

$0.5 \mathrm{ml}$. soybean inhibitor, usually containing $10 \mu \mathrm{g}$.

$1.0 \mathrm{ml}$. bovine fibrinogen, $0.2 \%$ in borate buffer.

The tubes are incubated for 10 minutes at $35^{\circ}$. At the end of this time $0.1 \mathrm{ml}$. of Hemostatic Globulin, diluted $1: 3$, is added and the formation of clots noted in 5-10 minutes. The method is based on Ferguson's (27) procedure for the fibrinogenolytic assay of tryptases. The lowest dilution of trypsin in which a clot forms contains trypsin equivalent to the soybean inhibitor in the test. It is necessary to allow the trypsin to act in the absence of Hemostatic Globulin because the Hemostatic Globulin preparations used con- 
tain some trypsin inhibitor. An advantage to this procedure, however, is that the addition of Hemostatic Globulin stops all tryptic activity, so that once the clots are formed, they are stable. Any desired range of trypsin concentration can be titrated by this method by using appropriate concentrations of inhibitor in the test. The sensitivity obtained depends on the interval between successive trypsin dilutions.

The inhibitor concentration of serum is determined as above with the substitution of dilutions of serum for the soybean inhibitor and the substitution of a fixed amount of active trypsin, usually about $10 \mu \mathrm{g}$., for the trypsin dilutions. The tube containing the highest dilution of serum in which a clot forms on addition of thrombin contains serum inhibitor equivalent to the trypsin in the test. Results are expressed as micrograms of active trypsin inhibited by $1 \mathrm{ml}$. serum.

The accuracy of the fibrinogenolytic test was compared with the method of Kunitz (13) for determining trypsin inhibitor, with results as shown in Table III.

TABLE III

Comparison of methods for serum inhibitor determination Inhibitor equivalent to micrograms trypsin inhibited per ml. serum

$\begin{array}{ccc}\begin{array}{c}\text { Serum } \\ \text { number }\end{array} & \begin{array}{c}\text { Kunitz } \\ \text { method }\end{array} & \begin{array}{c}\text { Fibrinogenolytic } \\ \text { method }\end{array} \\ 1 & 520 & 500 \\ 2 & 490 & 500 \\ 3 & 590 & 660\end{array}$

4. Plasminogen: Plasminogen determinations of serum are of doubtful accuracy because plasminogen cannot be separated quantitatively from serum, nor can the interfering substances, antistreptokinase and serum inhibitor, be removed or destroyed without loss of plasminogen. However, in samples of sera which are not abnormally high in antibody or inhibitor, the relative concentrations of plasminogen can be determined by activating with streptokinase and determining the least amount of activated serum necessary to lyse a standard clot. The details of the determination are as follows:

$0.5 \mathrm{ml}$. serial dilutions of serum in borate buffer

9 As noted above, Hemostatic Globulin is no longer available. Preliminary experiments with the more highlypurified bovine preparation of Parke-Davis indicates that they contain little or no inhibitor.
$0.1 \mathrm{ml}$. streptokinase solution, previously standardized as outlined below

$0.4 \mathrm{ml}$. bovine fibrinogen, $0.5 \%$ in borate buffer

$0.1 \mathrm{ml}$. Hemostatic Globulin, diluted 1:3.

The highest dilution of serum lysing the clot in 30 minutes at $35^{\circ}$ represents one unit of plasmin, or plasminogen.

It is necessary to activate the plasminogen in the presence of substrate, because, if this is not done, the total protease activity declines rapidly, probably because of the two-fold effect of autodigestion (25) and combination with serum inhibitor. Activation in the presence of substrate appears to minimize these effects. Since the activation of plasminogen by streptokinase appears to be a catalytic reaction $(2,14,28-31)$ it will be most efficient when an excess of streptokinase is used. A large excess of streptokinase would also prevent interference with the reaction by the antistreptokinase contained in variable amounts in practically all human sera. When attempts are made to use maximal amounts of crude streptokinase to activate serum plasminogen, an inhibitory effect is noted. This inhibitory effect of undiluted, concentrated crude streptokinase is due, probably, to the presence in crude streptokinase preparations of a protease inhibitor (14) which decreases in amount as streptokinase is purified. When purified streptokinase is used to activate a serum, maximum protease activity is obtained with the highest concentration of streptokinase, as shown in Table IV.

TABLE IV

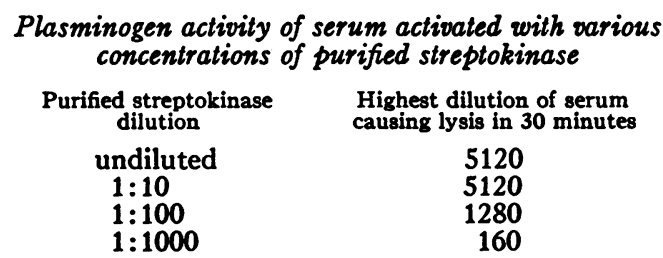

In addition to the absence of an inhibitory effect of high streptokinase concentration when using purified material, it can be seen from the data in Table $\mathrm{V}$ that the activity obtained is considerably higher than with the crude material. It is obvious, therefore, that activation with purified material is the method of choice. Unfortunately, it has not been possible in the past to obtain sufficient purified material for all requirements of the stud- 
ies involved in these reports. Therefore, protease determinations were made with selected batches of crude streptokinase, titrated to determine those lots and dilutions which would give the highest

\section{TABLE V}

Relation between maximum plasmin activity developed in serum by crude and purified streptokinase

$\begin{array}{lcc}\text { Serum } & \begin{array}{c}\text { Maximum } \\ \text { Crude } \\ \text { strepto- } \\ \text { kinase }\end{array} & \begin{array}{c}\text { plasmin activity } \\ \text { strifepto- } \\ \text { kinase }\end{array} \\ \text { L }(6-19-48) & 1280 & 3200 \\ \text { L (7-16-48) } & 640 & 1600 \\ \text { S } & 320 & 1280 \\ \text { B } & 160 & 1280 \\ \text { F } & 320 & 2560\end{array}$

values with normal sera. Such lots were set aside and used in all the protease determinations reported in the present studies. The results obtained, while not representing the maximal values, are useful as a measure of the relative plasminogen content of sera. The validity of this assumption is borne out by the observation (Table V) that a direct relation exists between the maximum amount of protease activity obtained on the activation of serum with crude and with purified streptokinase.

5. Desoxyribonuclease: The determination is carried out as described by McCarty (7), except that drop in relative viscosity is measured over a 10-minute instead of a 20-minute period of incubation. A unit is defined as the amount of enzyme necessary to cause a drop of 1 viscosity unit in 10 minutes at $30^{\circ}$ in a reaction mixture consisting of $2.4 \mathrm{ml}$. of desoxyribose nucleic acid and $0.1 \mathrm{ml}$. enzyme solution. The substrate consisted of a $0.15-0.2 \%$ solution of thymus desoxyribose nucleic acid in veronal buffer. The nucleic acid was prepared as described by Mirsky (32). Difficulty was encountered with the nucleic acid solutions in that a spontaneous drop in viscosity was noted. This effect could be eliminated by heating the nucleic acid solution to $56^{\circ}$ for about an hour. The heated solution, when used in the reaction mixture described above, had an initial relative viscosity of $4-5$ units.

\section{RESULTS}

1. Antistreptokinase: Evidence is abundant that an antibody to streptokinase appears following streptococcal infection $(18,33-36)$. In Table VI are presented the results obtained by using the methods described above.

TABLE VI

Antistreptokinase levels in various sera

\begin{tabular}{|c|c|c|c|}
\hline \multirow{2}{*}{ Serum } & \multirow{2}{*}{$\begin{array}{c}\text { No. } \\
\text { samples }\end{array}$} & \multicolumn{2}{|c|}{ Antistreptokinase units } \\
\hline & & Mean & Range \\
\hline $\begin{array}{l}\text { Normal } \\
\text { Infants (under } 1 \text { year) } \\
\text { Rheumatic fever } \\
\text { (children) }\end{array}$ & $\begin{array}{r}14 \\
9 \\
8\end{array}$ & $\begin{array}{r}36 \\
8 \\
1302\end{array}$ & $\begin{array}{c}4-80 \\
0-29 \\
100-4200\end{array}$ \\
\hline $\begin{array}{l}\text { Streptococcal pharyn- } \\
\text { gitis }\end{array}$ & 3 & 92 & $80-115$ \\
\hline $\begin{array}{l}\text { Tuberculous pleurisy } \\
\text { Dog } \\
\text { Monkey } \\
\text { Cow (pool) } \\
\text { Horse (pool) } \\
\text { Chicken }\end{array}$ & $\begin{array}{r}22 \\
3 \\
1\end{array}$ & $\begin{array}{r}87 \\
102 \\
66 \\
8 \\
4 \\
32\end{array}$ & $\begin{array}{r}2-400 \\
72-156\end{array}$ \\
\hline
\end{tabular}

Direct evidence that antistreptokinase is produced in humans following injection of streptokinase has been obtained in the present series of studies and is reported more fully in the accompanying paper (1). In Table VII are shown the antibody titrations in the serum of two patients following the intrapleural injection of purified streptokinase. The antibody responses seen in the two patients reported in Table VII are perhaps

TABLE VII

Rise in antistreptokinase following intrapleural Patient injection of purified streptokinase

M. H. (female)

Date
$6 / 8(200,000$ SK in-
jected intrapleurally $)$
$6 / 11$
$6 / 17$
$6 / 22$

ASK units

M. H. (female)

Patient

C. L. (male)

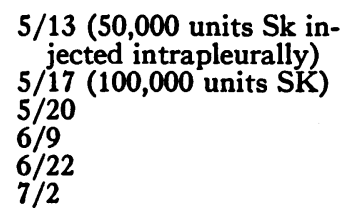

40

5120

over 10,000 over 10,000

5120

somewhat more rapid than is usual as a primary response to the injection of an antigen. The rapidity of the response, however, is probably due to the fact that the response is an anamnestic one, since it will be noted that both patients had a titer before injection of streptokinase. In fact, all human sera tested have had some antibody, even 
with no known history of streptococcal infection.

2. Serum inhibitor: The values obtained for a variety of sera are presented in Table VIII. Results are expressed as micrograms of active trypsin inhibited by $1 \mathrm{ml}$. of serum.

\section{TABLE VIII}

Serum inhibitor levels of serum from man and animals

\begin{tabular}{|c|c|c|c|}
\hline \multirow{2}{*}{ Serum } & \multirow{2}{*}{$\begin{array}{l}\text { No. of } \\
\text { samples }\end{array}$} & \multicolumn{2}{|c|}{$\begin{array}{c}\text { Serum inhibitor as micro- } \\
\text { grams trypsin inhibited } \\
\text { per ml. }\end{array}$} \\
\hline & & Mean & Range \\
\hline $\begin{array}{l}\text { Normal adult } \\
\text { Infants (under 1) } \\
\text { Rheumatic children } \\
\text { Pulmonary tuberculosis } \\
\text { Carcinoma } \\
\text { Leukemia } \\
\text { Chicken } \\
\text { Rabbit } \\
\text { Horse (pool) } \\
\text { Dog } \\
\text { Guinea pig }\end{array}$ & $\begin{array}{r}16 \\
9 \\
5 \\
7 \\
4 \\
5 \\
1 \\
1 \\
2 \\
1 \\
2\end{array}$ & $\begin{array}{r}655 \\
613 \\
760 \\
1035 \\
883 \\
1096 \\
264 \\
400 \\
765 \\
365 \\
2125\end{array}$ & $\begin{array}{l}100-1200 \\
420-1024 \\
570-900 \\
660-1500 \\
600-1333 \\
842-1350 \\
670-860 \\
1750-2500\end{array}$ \\
\hline
\end{tabular}

The data presented are obviously too scanty to warrant the drawing of conclusions. However, the finding that the value is elevated in chronic wasting diseases such as tuberculosis and malignancies is in accord with many earlier observations on serum inhibitor (see Grob [21] for references).

The values for animal sera tested lie within the range of normal human values, with the exception of guinea pigs, which, at least in the few specimens tested, have an abnormally high value.

TABLE IX

Levels of plasminogen in various sera

\begin{tabular}{l|c|c|c}
\hline \multirow{2}{*}{ Serum } & $\begin{array}{c}\text { No. of } \\
\text { specimens }\end{array}$ & \multicolumn{2}{|c}{ Units of plasminogen } \\
\cline { 4 - 5 } & & Mean & Range \\
\hline Normal adult & 8 & 572 & $160-1280$ \\
Rheumatic children & 3 & 960 & $320-1280$ \\
Tuberculosis & 6 & 4053 & $1280-5120$ \\
Carcinoma & 1 & 2560 & \\
Non-rheum. H. D. & 5 & 576 & $320-640$ \\
Chicken & 1 & Less than 10 units \\
Monkey & 2 & Less than 10 units \\
Dog & 3 & Less than 10 units \\
Cattle (pool) & 1 & Less than 10 units \\
\hline
\end{tabular}

Of interest are the somewhat higher values for rheumatic children. If these differences are significant, their relation to the higher plasminogen values obtained for rheumatics (Table IX) is of importance, suggesting the possibility that the inhibitor might serve a role in relation to plasminogen. However, when one considers the inhibitor and plasminogen values obtained with animal sera, no relationship appears to exist, since the inhibitor level is high while the amount of plasminogen activatable by streptokinase is negligible.

3. Plasminogen: The deficiencies of the method for plasminogen determination have been discussed above. The results obtained are presented in Table IX.

In spite of the deficiencies of the method, the results obtained with normal sera have been reasonably uniform, the great majority of them showing levels of 320 or 640 units. Retitration of a single serum, or titrations of successive bleedings of the same individual show a variation of no more than one tube in the series. The higher values obtained with certain of the patients under investigation (e.g., tuberculous and carcinomatous) probably represent an increase over normal, even though the method of titration does not give maximal values for any serum. If these values are artifacts and do not represent an increase of total plasminogen over normal, it is difficult to account for the results, since the two substances in serum known to influence the reaction, serum inhibitor and antistreptokinase, would both tend to decrease, rather than increase the plasminogen values.

\section{SUM MARY}

A method for purification of streptokinase describes conditions for obtaining high yields from bacterial cultures. Protamine is used to remove impurities and streptokinase is separted from desoxyribonuclease with cold ethanol at $20 \%$ concentration. The desoxyribonuclease is precipitated with $40-50 \%$ cold ethanol. The yield of streptokinase is about $25 \%$ and the product so obtained has been used in clinical studies.

Method's are briefly described for the quantitative estimation of streptokinase, antistreptokinase, serum inhibitor, serum plasminogen, and desoxyribonuclease. These methods were employed to make a survey study of various sera. There is a marked rise in antistreptokinase activity following intrapleural injection of streptokinase in human beings. Serum from the normal 
adult contains more antistreptokinase than serum from the infant and the level is strikingly high in rheumatic fever. In various species the concentration decreases in the following order: dog, monkey, man, chicken, cow and horse. Serum inhibitor levels show elevations in wasting diseases, and in the animals studied the guinea pig has an exceptionally high inhibitor titer. The method for plasminogen determination presents difficulties but it appears that there may be a marked increase in patients with tuberculosis. The concentration in chicken, monkey, dog, and cattle appears to be low.

Serum can be heated at $56^{\circ} \mathrm{C}$ for 30 minutes to destroy serum inhibitor but antistreptokinase is not destroyed.

\section{BIBLIOGRAPHY}

1. Tillett, W. S., and Sherry, Sol, The effect in patients of streptococcal fibrinolysin (streptokinase) and streptococcal desoxyribonuclease on fibrinous, purulent and sanguinous pleural exudations. J. Clin. Invest., 1949, 28, 173.

2. Christensen, L. R., Streptococcal fibrinolysis: A proteolytic reaction due to a serum enzyme activated by streptococcal fibrinolysin. J. Gen. Physiol., 1945, 28, 363.

3. Christensen, L. R., Protamine purification of streptokinase and effect of $\mathrm{pH}$ and temperature on reversible inactivation. J. Gen. Physiol., 1947, 30, 465.

4. Pillemer, Louis, and Hutchinson, M. C., The determination of the albumin and globulin contents of human serum by methanol precipitation. J. Biol. Chem., 1945, 158, 299.

5. Sherry, Sol, Tillett, William S., and Christensen, L. R., Presence and significance of desoxyribose nucleoprotein in the purulent pleural exudates of patients. Proc. Exper. Biol. \& Med., 1948, 68, 179.

6. Tillett, W. S., Sherry, Sol, and Christensen, L. R., Streptococcal desoxyribonuclease: Significance in lysis of purulent exudates and production by strains of hemolytic streptococci. Ibid., 184.

7. McCarty, Maclyn, The occurrence of nucleases in culture filtrates of group A hemolytic streptococci. J. Exper. Med., 1948, 88, 181.

8. McCarty, Maclyn, Purification and properties of desoxyribonuclease isolated from beef pancreas. J. Exper. Med., 1946, 29, 123.

9. Edsall, John T., The plasma proteins and their fractionation, in Advances in Protein Chemistry, Vol. III, edited by Anson, M. L., and Edsall, John T. Academic Press, Inc., New York, 1947.

10. Milstone, H., A factor in normal blood which participates in streptococcal fibrinolysis. J. Immunol., 1941, 42. 109.
11. Oncley, J. L., Melin, M., Richert, D. A., Cameron, J. W., and Gross, P. M., Jr. In press.

12. Cohn, E. J., Strong, L. E., Hughes, W. L., Jr., Mulford, D. W., Ashworth, J. N., Melin, M., and Taylor, H. L., Preparation and properties of serum and plasma proteins. IV. A system for the separation into fractions of the protein and lipoprotein components of biological tissues and fluids. J. Am. Chem. Soc., 1946, 68, 459.

13. Kunitz, M., Crystalline soybean trypsin inhibitor. J. Gen. Physiol., 1946, 29, 149; ibid., 30, 291.

14. Christensen, L. R., and MacLeod, Colin M., A proteolytic enzyme of serum: characterization, activation, and reaction with inhibitors. J. Gen. Physiol., 1945, 28, 559.

15. Garner, R. L., and Tillett, W. S., Biochemical studies on the fibrinolytic activity of hemolytic streptococci : I, II. J. Exper. Med., 1934, 60, 239, 255.

16. Christensen, L. R., Quantitative determination of activity of streptococcal fibrinolysin. Proc. Exper. Biol. \& Med., 1941, 46, 674.

17. Holmberg, C. G., and Winbald, S., Purification and concentration of streptococcal fibrinolysin from broth cultures. Path. et Microbiol. Scand., 1944, 21, 833.

18. Kaplan, Melvin H., Studies of streptococcal fibrinolysis: II. The inhibition of streptococcal fibrinolysis by antifibrinolysin and antiprotease. J. Clin. Invest., 1946, 24, 337.

19. Anderson, H. C., Kunkel, H. G., and McCarty, Maclyn, Quantitative antistreptokinase studies, etc. J. Clin. Invest., 1948, 27, 425.

20. Massell, B. F., Mote, J. R., and Jones, T. D., The quantitative relation of fibrinolysin and antifibrinolysin. J. Immunol., 1939, 36, 45.

21. Grob, D., The antiproteolytic activity of serum. I. The nature and experimental variation of the antiproteolytic activity of serum. J. Gen. Physiol., 1943, 26, 405.

22. Guest, M. M., Ware, A. B., and Seegers, W. H., A quantitative study. of antifibrinolysin in chick plasma: Increase in antifibrinolysin activity during pteroylglutamic acid deficiency. Am. J. Physiol., 1947, 150, 661.

23. Croxatto, H., and Croxatto, R., Effect of chloroform on the antitryptic activity of blood plasma. Proc. Soc. Exper. Biol. \& Med., 1947, 66, 191.

24. Schmitz, A., Uber den Trypsin-Inhibitor des Blutes. Ztschr. f. physiol. Chem., 1938, 255, 234.

25. Christensen, L. R., The activation of plasminogen by chloroform. J. Gen. Physiol., 1946, 30, 149.

26. Edsall, John T., personal communication.

27. Ferguson, J. H., Assay of tryptases by lysis of fibrinogen. Proc. Soc. Exper. Biol. \& Med., 1943, 52, 243.

28. Christensen, L. R., The mechanism of streptococcal fibrinolysis. J. Bact., 1944, 47, 471.

29. Holmberg, C. G., Studies on the splitting of fibrin under the influence of fibrinolysin from hemolytic 
streptococci. Arkiv für Kemi, Minerologie o. Geologic, 1943, 17, 1.

30. Kaplan, M. H., Studies of streptococcal fibrinolysis. I. The dissimilarity of serum protease and trypsin as indicated by the separate specificities of their kinases, fibrinolysin and enterokinase. J. Clin. Invest., 1946, 25, 331.

31. Astrup, T., 1948, personal communication.

32. Mirsky, A. E., and Pollister, A. W., Chromosin, a desoxyribose nucleoprotein complex of the cell nucleus. J. Gen. Physiol., 1946, 30, 117.
33. Tillett, W. S., The fibrinolytic activity of hemolytic streptococci. Bact. Rev., 1938, 2, 161.

34. Mote, J. R., and Jones, T. D., Studies of hemolytic streptococcal antibodies in control groups, rheumatic fever, and rheumatoid arthritis, I, II and III. J. Immunol., 1941, 41, 35, 61, 87.

35. Boisvert, Paul L., The streptococcal antifibrinolysin test in clinical use. J. Clin. Invest., 1940, 19, 65.

36. Commission of Acute Respiratory Diseases, Studies of streptococcal fibrinolysis. IV. Clinical application of a quantitative antifibrinolysin test. J. Clin. Invest., 1946, 25, 352. 